\title{
PENGARUH RETURN ON INVESTMENT DAN DEBT TO EQUITY RATIO TERHADAP RETURN SAHAM PADA PERUSAHAAN YANG TERGABUNG DI JAKARTA ISLAMIX INDEX
}

\author{
Aryanti ${ }^{1}$, Aziz Septiatin ${ }^{2}$ \\ Universitas Islam Negeri Raden Fatah, Palembang ${ }^{1}$ \\ aryantifebi_uin@radenfatah.ac.id \\ Universitas Islam Negeri Raden Fatah, Palembang2 \\ azizseptiatin_uin@radenfatah.ac.id
}

\begin{abstract}
One option in investing is through investing in the stock market. In obtaining stock returns can be done by analyzing the company's financial performance by conducting a ratio analysis. In this study the ratio used is return on investment (ROI) and debt to equity ratio (DER). The purpose of this study was to determine the effect of return on investment and the debt to equity ratio on stock returns in companies incorporated in the Jakarta Islamic Index for the period 2010-2016. The type of data in this study is secondary data. Techniques for collecting data using financial statements. The data analysis technique used in this study is variable descriptive statistical analysis, classical assumption test analysis, multiple linear regression, and hypothesis testing. The study sample consisted of 10 companies. The results showed that the return on investment (ROI) significantly affected stock returns, and the debt to equity ratio had a significant effect on stock returns.
\end{abstract}

Keywords: Return On Investment (ROI), Debt To Equity Ratio (DER), Return

\section{PENDAHULUAN}

Pasar modal merupakan sarana dalam melakukan investasi bagi para pemodal (investor) dalam melakukan diversifikasi investasi untuk membentuk portofolio yang sesuai dengan risiko. Dalam melakukan investasi, apakah investasi akan memberikan tingkat pengembalian yang diharapkan, maka calon investor terlebih dahulu mencari informasi keuangan perusahaan melalui laporan keuangannya. Laporan keuangan merupakan produk akhir dari serangkaian proses pencatatan dan pengikhtisaran data transaksi bisnis. Jika kondisi keuangan baik, dan kinerja perusahaan baik, maka pasar akanmerespon dengan positif harga saham perusahaan sehingga para investor bisa mendapatkan tingkat pengembalian yang diharapkan.

Dalam memperoleh keuntungan yang diinginkan, maka seorang investor perlu melakukan analisis keuangan dalam melihat prospek dan risiko perusahaan. Prospek bisa dilihat dari tingkat keuntungan dan risiko bisa dilihat dari kemungkinan perusahaan mengalami kesulitan keuangan atau mengalami kebangkrutan.

Dari sudut pandang investor, salah satu indikator penting untuk menilai prospek perusahaan di masa datang adalah dengan melihat sejauh mana pertumbuhan profitabilitas (keuntungan) perusahaan dan perkembangan hutang. Indikator ini sangat penting 
diperhatikan untuk mengetahui sejauh mana investasi yang akan dilakukan investor di suatu perusahaan sehingga mampu memberikan return yang sesuai dengan tingkat yang disyaratkan investor.

Salah satu rasio keuangan yang sering dipakai dalam menganalisis Return Sabam adalah Return on Investment (ROI) dan Debt to Equity Ratio (DER). Return saham merupakan tujuan utama seorang investor dalam berinvestasi yaitu untuk mendapatkan keuntungan dari investasinya tersebut. Investor yang melakukan investasi dalam bentuk saham akan selalu memperhitungkan hasil atas Return yang diperolehnya. Investor tersebut akan memperoleh dua bentuk hasil dari investasi saham yang berupa deviden dan capital gain. Capital gain merupakan selisih dari harga saham periode sekarang dengan periode sebelumnya. Sedangkan deviden adalah penerima dari perusahaanyang berasal dari laba yang dibagikan investor perlu melakukan evaluasi atauanalisis kinerja terhadap perusahaan.

Jakarta Islamic Index adalah indeks bursa saham atau indeks harga rata-rata saham yang mulai dibuat pada tanggal 3 juli 2000 untuk memfasilitasi perdagangan perusahaan publik yang dijalankan sesuai syariah.Alasan penulis memilih objek penelitian Jakarta Islamic Index (JII) karena JII merupakan indeks saham yang memenuhi kriteria dipasar modal berdasarkan sistem syariah Islam sehingga mendapatkan perhatian yang cukup besar terhadap kebangkitan perekonomian Islam saat ini. Terdapat 10 perusahaan di Jakarta IslamicIndex (JII) yang memenuhi kriteria. Saham-saham tersebut diseleksi berdasarkan keaktifan perusahaan dalam mempublikasikan laporan keuangannya.

Rata-ratareturn saham perusahaan yang terdaftar di Jakarta IslamicIndex (JII) dari tahun 2013 sampai dengan tahun 2016 tertinggi terdapat pada perusahan LPKR yaitu sebesar $368 \%$.Untuk rata-rata return saham yang paling rendah terdapat pada perusahaan CPIN sebesar $49 \%$. Rata-rata return saham tertinggi disebabkan oleh tingkat harga saham yang stabil dan juga kinerja perusahaan yang semakin baik sehingga menyebakan tingkat profitabilitas semakin tinggi.Sebaliknya return saham yang turundisebabkan oleh harga saham yang kurang stabil sehingga menyebabkan tingkat profitabilitas semakin turun.(Sumber:wmw.idx.co.id (data diolab))

Dalam melakukan investasi, investor biasanya menghindari risiko. Semakin tinggi risiko perusahaan mengakibatkan perusahaan tidak mampu untuk membayar hutang artinya semakin tinggi debt to equity ratio(DER) akanmengakibatkan saham perusahaan tersebut dihindari investor, sehingga harga saham semakin rendah dengan menunjukan debt to equity ratio(DER) berarti akan meningkatkan risiko berinvestasi, dengan demikian investor merespon negatif terhadap kinerja perusahaan. Rendahnya kinerja perusahaan berakibat harga saham akan mengalami penurunan. Menurunnya harga saham akan mengakibatkan return yang semakin menurun.

Debt to Equity Ratio (DER) mencerminkan kemampuan perusahaan dalam memenuhi seluruh kewajibannya yang ditunjukkan oleh berapa bagian dari modal sendiri yang digunakan untuk membayar hutang. DER menunjukkan tentang imbangan antara beban hutang dibandingkan modal sendiri. DER juga memberikan jaminan tentang seberapa besar 
hutang-hutang perusahaan dijamin modal sendiri. (Brigham (Brigham dan Gapenski, 1997: 767-768)

Berdasarkanhasil penelitian-penelitian terdahulu dapat disimpulkan bahwa rasio keuangan yang dapat digunakan untuk memprediksi return saham antara lain return on investment (ROI)dan debt to equity ratio (DER) digunakan untuk mengukur kinerja perusahaan yang memberikan hasil bervariasi sehingga menimbulkan pertanyaan untuk diteliti lebih lanjut.

Husnan dan Pudjiastuti (2005:70) berpendapat bahwa "debt to equity ratio (DER) merupakan rasio yang menunjukkan perbandingan antara hutang dengan modal sendiri". Berdasarkan pendapat di atas, debt to equity ratio (DER) digunakan untuk mengukurkemampuan perusahaan dalam menutupsebagain atau seluruh hutang-hutangnya baik jangka panjang maupun jangka pendekdengan dana yang berasal dari total modal dibandingkan besar hutang. Olah karena itu, semakin rendah DER akan semakin tinggi kemampuan perusahaan untuk membayar seluruh kewajibannya. Semakin besar proporsi hutang yang digunakan untuk struktur modal suatu perusahaan, maka akan semakin besar pula jumlah kewajibannya.

Raisa Fitri (2017) melakukan penelitian mengenai Kebijakan Dividen, LeveragePerusahaan dan Profitabilitas terhadap Return Saham di BEI. Hasil penelitian menunjukkan secara parsial bahwa DER tidak berpengaruh terhadap return saham. Hasil penelitian ini tidak sejalan dengan penelitian yang dilakukan olehEka Novi Wijayanti (2012) dalam penelitiannya yang berjudul "Analisis Pengaruh Kinerja Keuangaan Terhadap Return Saham pada Perusahaan Manufaktur yang Terdaftar di Bursa Efek Indonesia Tahun 2007 2009". Hasil penelitian menunjukkan bahwa DER secara parsial memiliki pengaruh signifikan terhadap return saham.

Selain itu penelitian mengenai ROI terhadap Return saham telah dilakukan oleh Mabrur Ali (2011), dalam penelitiannya yang berjudul "Pengaruh Economic Value added, Return On Investment, Debt to Equity Ratio, dan Arus Kas operasi Terhadap return saham Perusahaan Properti dan Real State. Hasil Penelitian menunjukkan bahwa ROI berpengaruh signifikan terhadap return saham. Akan tetapi hasil penelitian ini tidak sejalan dengan penelitian yang dilakukan oleh Rachmi Wijaya (2009) mengenai pengaruh ROI terhadap return saham. Hasil penelitian menunjukkan bahwa ROI tidak berpengaruh terhadap return saham.

Tujuan penelitian ini adalah untuk melihat pengaruh Return On Investment (ROI) dan Debt To Equity Ratio (DER) terhadap return saham Pada perusahaan yang tergabung di Jakarta Islamic Indexperiode 2010-2016

\section{LITERATUR REVIEW DAN PENGEMBANGAN HIPOTESIS Return Saham}

Menurut Tandelilin, Return merupakan salah satu faktor yang memotivasi investor berinvestasi dan juga merupakan imbalan atau keberanian investor menanggung resiko atas investasi yang dilakukan. Sumber-sumber return investasi terdiri dari dua komponen utama 
yaitu yield dan capital gain (loss). Yield merupakan komponan return yang mencerminkan aliran kas atau pendapatan yang diperoleh secara periodik dari suatu investasi. Jika investor membeli saham, yield ditunjukan oleh besarnya deviden yang investor peroleh. Sedangkan capital gain (loss) sebagai komponen kedua dari return merupakan kenaikan (penurunan) harga suatu surat berharga (bisa saham maupun surat hutang jangka panjang) yang bisa memberikan keuntungan (kerugian) bagi investor.

Menurut Jogiyanto, return merupakan hasil yang diperoleh dari investasi. Return dapat berupa return realisasi (realized return) dan return ekspektasian (expected return).Return realisasi(realized return) merupakan return yang telah terjadi. Return realisasi menggunakan data historis. Return realisasi penting karena digunakan sebagai salah satu pengukur kinerja dari perusahaan. Return realisasi atau return historis ini juga berguna sebagai dasar penentuan return ekspektasian (expectedreturn) dan resiko dimasa mendatang return ekspektasian (expected return) adalah return yang diharapkan akan diperoleh oleh investor dimasa mendatang. Berbeda dengan return realisasi yang bersifat sudah terjadi, return ekspektasian sifatnya belum terjadi.

Dalam penelitian ini, retirn yang digunakan adallah capital gain(loss). Rumus menghitung return:

Keterangan:

$$
\text { Returnsaham }=\frac{\mathbf{P}_{\mathrm{t}}-\mathbf{P}_{\mathrm{t}-1}}{\mathbf{P}_{\mathrm{t}-1}} \times 100 \%
$$

$\mathrm{P}_{\mathrm{t}} \quad$ = Harga saham sekarang

$\mathrm{P}_{\mathrm{t}-1} \quad=$ Harga saham period e sebelumnya

\section{Return on Investment (ROI)}

Return on investment (ROI) atau pengambalian investasi, bahwa dibeberapa referensi lainnya rasio ini juga ditulis dengan return on total asset (ROA). Rasio ini melihat sejauh mana investasi yang telah ditanamkan mampu memberikan pengembalian keuntungan sesuai dengan yang diharapkan. Dan investasi tersebut sebenarnya sama dengan asset perusahaan yang ditanamkan atau ditempatkan.

ROI merupakan analisis pengembalian atas investasi modal yang membandingkan laba perusahaan, atau ukuran kinerja lainnya, terhadap tingkat dan sumber pendanaan perusahaan. Analisis ini menentukan kemampuan perusahaan untuk meraih keberhasilan, memperoleh pendanaan, membayar kreditor dan memberikan imbalan kepada pemilik. Adapun rumus return on investment (ROI) adalah:

$$
\text { ROI }=\frac{\text { EarningAfterTax }(E A T)}{\text { TotalAssets }} \times 100 \%
$$

\section{Debt to Equity Ratio (DER)}

Debt to equity ratio (DER) merupakan rasio yang digunakan untuk menilai utang dengan ekuitas. Rasio ini dicari dengan cara membandingkan antara seluruh utang, termasuk utang lancar dengan seluruh ekuitas. Rasio ini digunakan untuk mengetahui jumlah dana yang disediakan peminjam (kreditor) dengan pemilik perusahaan. Dengan kata lain rasio ini berfungsi untuk mengetahui setiap rupiah modal sendiri yang dijadikan jaminan barang. 
Bagi bank (kreditor), makin besar rasio ini akan makin tidak menguntungkan karena makin besar rasiko yang ditanggung atas kegagalan, namun bagi perusahaan sangat menguntungkan dan sebaliknya. DER untuk setiap perusahaan tantu berbeda-beda, perusahaan dengan arus kas yang stabil biasanya memiliki rasio yang tinggi dari rasio kas yang kurang stabil (Kasmir,2008).Debt to Equily Ratio(DER) dapat dirumuskan sebagai berikut:

$$
\text { DER }=\frac{\text { TotalDebt }}{\text { TotalEquity }} \times 100 \%
$$

\section{Hipotesis}

Berdasarkan hasil penelitian-penelitian terdahulu, maka hipotesis dalam penelitian ini sebagai berikut:

$\mathbf{H}_{1}$ : Return on Investment (ROI) berpengaruh terhadap return saham

$\mathbf{H}_{2}$ : Debt to Equity Ratio (DER) berpengaruh terhadap return saham

\section{Kerangka Pemikiran}

Berdasarkan hasil penelitian terdahuludan pengembangan hipotesis serta permasalahan yang telah dikemukakan, maka dapat dirumuskan melalui suatu kerangka pemikiran sebagai berikut:

\section{Gambar 1}

Kerangka Pemikiran

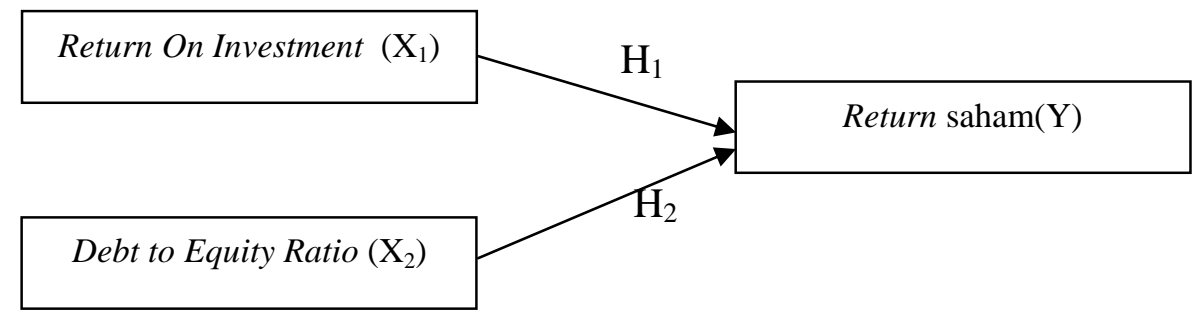

\section{METODE PENELITIAN}

\section{Jenis Penelitian}

Jenis penelitian ini adalah kuantitatif, yaitu penelitian yang menganalisis data secara kuantitatif kemudian menginterprestasikan hasil analisis tersebut untuk memperoleh suatukesimpulan.Jenis penelitian kuantitatif dalam penelitian ini adalah mengolah data-data laporan keuangan perusahaan emiten yang tergabung dalam Jakarta Islamic Index periode 2010-2016 dan data harga saham (closing price)perusahaan emiten yang tergabung dalam Jakarta Islamic Indek 2010-2016.

\section{Sampel}

Pemilihan sampel dalam penelitian ini dengan menggunakan teknikpurposive sampling yaitu dengan menggunakan kriteria tertentu yang ditempuhdalam pengambilan sampel yang diteliti. Kriteria yang digunakan dalam penelitian ini adalah:

a. tersedianya data laporan keuangan selama periode penelitian (tahun 2010-2016) per tahun. 
b. fokus pada saham-saham perusahaan yang muncul terus menerus selama periode penelitian (tahun 2010-2016)..

c. Perusahaan tersebut terdaftar di Jakarta Islamic Index(JII) pada periode 2010-2016.

Berdasarkan kriteria tersebut, diperoleh 11 perusahaan yang memenuhi syarat untuk dijadikan sampel, sebagagi berikut:

Tabel 1

Emiten yang Akan Diteliti

\begin{tabular}{cl}
\hline No & \multicolumn{1}{c}{ Nama Perusahaan } \\
\hline 1 & Alam Sutera Realty Tbk (ASRI) \\
2 & Vale Indonesia Tbk (INCO) \\
3 & Indocement Tunggal Prakasa Tbk (INTP) \\
4 & Kalbe Farma Tbk (KLBF) \\
5 & Lippo Karawaci Tbk (LPKR) \\
6 & PP London Sumatra Indonesia Tbk (LSIP) \\
7 & Semen Gresik (Persero) Tbk (SMGR) \\
8 & Telekomunikasi Indonesia Tbk (TLKM)) \\
9 & United Tractors Tbk (UNTR) \\
10 & Unilever Indonesia Tbk (UNVR) \\
\multicolumn{2}{c}{ Sumber: idx.co.id (diunduh tahun 2017) }
\end{tabular}

\section{Jenis dan Sumber Data}

Jenis data yang digunakan dalam penelitian ini adalah data kuantitatif berupa data sekunder, data tersebut dikategorikan sebagai data time series yang diambildari periode tahun 2010-2016. Data yang dibutuhkan dalam penelitian ini adalah:

a. Data perusahaan emiten yang terdaftar di Jakarta Islamic Index periode tahun 20102016.

b. Data harga saham (closing price) perusahaan emiten yang terdaftar di Jakarta Islamic Index periode tahun 2010-2016.

c. Data laporan keuangan dari perusahaan emiten yang terdaftar di Jakarta Islamic Index (JII) periode tahun2010-2016.

Jenis data yang akan digunakan dalam penelitian ini berupa data harga penutupan saham (closing price) dan data laporan keuangan emiten yang dapat diunduh dari website www.idx.co.id, www.sahamok.com dan melalui Indonesia Capital Market Directory (ICMD).

\section{Teknik Pengumpulan Data}

Teknik pengumpulan data dalam penelitian ini dengan mengunakan teknik dokumentasi.Secara teknis pengumpulan data dalam penelitian ini dilakukan dengan pencarian data melalui website www.idx.co.id, www.sahamok.com dan melalui Indonesia Capital Market Directory (ICMD) dalam rangka mengumpulkan data seluruh variabel penelitian. 


\section{Teknik Analisis Data}

Metode analisis data yang digunakan dalam penelitian ini adalah dengan menggunakan metode Asumsi klasik, metode analisis regresi linier berganda dam uji hipotesis.

\section{HASIL PENELITIAN}

\section{Hasil Uji Asumsi Klasik}

\section{Uji Normalitas}

Pengujian normalitas dilakukan untuk mengetahui normal atau tidaknya suatu distribusi data. Hal ini penting diketahui karena berkaitan dengan ketepatan pemilihan teknik uji yang akan digunakan. Dalam penelitian ini menggunakan uji gambar grafik histogram dan uji normalitas P-P Plot.

Uji normalitas tidak hanya dilakukan dengan grafik histogram tetapi juga dengan uji Normal P-P Plot.

\section{Gambar 2}

Hasil Uji Normalitas

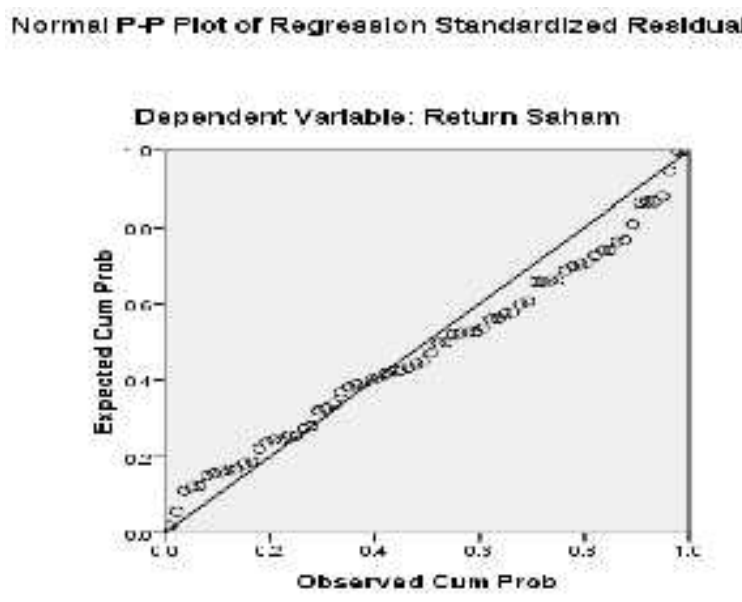

Grafik normal plotdapat disimpulkan bahwa grafik ini menunjukkan model regresi memenuhi asumsi normalitas. Karena pada grafik normal plot data menyebar disekitar garis diagonal dan mengikuti arah garis diagonal.

\section{Uji Linearitas}

Uji linearitas digunakan untuk mengetahui apakah dua variabel antara variabel $\mathrm{X}$ dan variabel $\mathrm{Y}$ yang mempunyai hubungan yang linier.

\section{PEMBAHASAN}

\section{Pengaruh Return On Investment (ROI) Terhadap Return Saham Perusahaan}

Hipotesis pertama menyatakan bahwa Return On Investment (ROI) berpengaruh signifikan terhadap return saham. Dari hasil uji parsial pada tabel 8 menunjukkan bahwa nilai Return On Investmen (ROI) berpengaruh terhadap return saham dengan nilai signifikan 0,003 . Nilai signifikan tersebut lebih kecil dari 0,05 . Selain itu dari hasil perbandingan antara $t_{\text {hitung }}$ dan $t_{\text {tabel }}$ yang menunjukkan bahwa nilai $t_{\text {hitung }}$ sebesar 2.743 $>t_{\text {tabel }}$ 1.667. Maka dapat 
disimpulkan bahwa return on investment (ROI) berpengaruh positif dan signifikan terhadap return saham perusahaan.

Return on investment (ROI) menunjukkan kemampuan perusahaan menghasilkan laba atas aktiva, semakin tinggi nilai return on investment (ROI) semakin baik keadaan suatu perusahaan. Apabila laba atas aktiva semakin tinggi maka harga saham juga akan semakin besar begitu juga dengan return saham. Jadi dapat disimpulkan bahwa dengan meningkatnya laba yang dihasilkan suatu perusahaan maka akan menaikkan pula harga saham perusahaan tersebut. Hal ini terjadi dikarenakan banyak para investor yang tertarik dengan laba yang dihasilkan sehingga akan menarik minat investor untuk membeli saham perusahaan pun akan meningkat.

Hasil penelitian ini sejalan dengan penelitian yang dilakukan oleh Mabrur Ali (2011)Hasil Penelitian menunjukkan bahwa ROI berpengaruh signifikan terhadap return saham. Akan tetapi hasil penelitian ini tidak sejalan dengan penelitian yang dilakukan oleh Rachmi Wijaya (2009)mengenai pengaruh ROI terhadap return saham. Hasil penelitian menunjukkan bahwa ROI tidak berpengaruh terhadap return saham. Hal ini dikarenakan nilai ROI perusahaan yang terdaftar di Jakarta Islamic Index (JII) rata-rata mengalami kenaikan yang menyebabkan laba perusahaan akan semakin meningkat.

\section{Pengaruh Debt To Equity Ratio (DER) Terhadap Return Saham Perusahaan}

Hasil penelitian menyatakan bahwadebt to equity ratio (DER) berpengaruhsignifikan terhadap return saham. Dari hasil uji pada tabel 8 menunjukkan bahwa nilai debt to equity ratio (DER) berpengaruh terhadap return saham dengan nilai signifikan 0,000. Selain dari hasil perbandingan antara $t_{\text {hitung }}$ dan $t_{\text {tabel }}$ menunjukkan bahwa nilai $t_{\text {hitung }}$ sebesar 3.894 $>t_{\text {tabel }} 1.667$ sehingga dapat disimpulkan bahwa debt to equity ratio (DER) berpengaruh positif signifikan terhadap return saham perusahaan sehingga kondisi ini menyebabkan berkembangnya perusahaan dimasa yang akan datang yang dapat meningkatkan nilai return saham.

Hal ini menyebabkan semakin tinggi nilai debt to equity ratio (DER) semakin tinggi pula nilai return saham. Debt to equity ratio(DER) menunjukkan proporsi atas penggunaan utang untuk membiayai investasinya. Apabila penggunaan DER semakin tinggi maka utang perusahaan juga akan semakin tinggi. Utang yang tinggi dapat menunjukkan risiko yang tinggi sehingga dapat dikatakan bahwa risiko yang tinggi berbanding lurus dengan return yang tinggi. Sehingga peningkatan terhadap nilai debt to equity ratio(DER) direaksi secara positif oleh pasar sehingga berdampak pada peningkatan harga saham dan return saham.

Sesuai dengan teori saham yang menyatakan bahwa bigh risk return risiko dari suatu perusahaan ditandai dengan tingkat debt to equity ratio (DER) yang dimilikinya. Hasil yang didapatkan mengindikasikan bahwa adanya pertimbangan yang berbeda dari sebagian investor dalam memandang debt to equity ratio (DER). Beberapa investor memiliki sifat suka mengambil risiko (risk seeker) yang akan cenderung memilih saham-saham yang memiliki tingkat debt to equity ratio (DER) yang tinggi. Sehingga ketika nilai debt to equity ratio (DER) semakin tinggi maka akan memperbesar tanggungan yang dimiliki perusahaan. Namun demikian dari beberapainvestor justru memandangbahwa perusahaan yangtumbuh pastinya akan memerlukan hutang sebagai dana tambahan guna memenuhi pendanaan didalam perusahaan.

Hasil penelitian ini sejalan dengan penelitian yang dilakukan oleh Eka Novi Wijayanti (2012) yang menyimpulkan bahwa debt to equity ratio (DER) berpengaruh terhadap return saham akan tetapi hasil penelitian ini tidak sejalan dengan penelitian yang dilakukan oleh Raisa Fitri (2017) yang menyatakan bahwa DER tidak berpengaruh terhadap return 
saham. Sehingga dapat dikatakan bahwa DER digunakan untuk mengukur kemampuan perusahaan dalam menutupi sebagian atas seluruh hutang-hutangnya baik jangka pendek maupun hutang jangka panjang. Oleh karena itu semakin rendah nilai DER akan semakin tinggi kemampuan perusahaan dalam memenuhi kewajibannnya.

\section{KESIMPULAN}

\section{Kesimpulan}

Berdasarkan hasil analisis pada penelitian ini, maka dapat ditarik kesimpulan bahwa Return On Investment(ROI) berpengaruh terhadap return saham. Begitu juga dengan Debt to Equity Ratio (DER) yang berpengaruh terhadap return saham pada perusahaan yang tergabung di Jakarta Islamic Index (JII) pada periode 20102016.

\section{Saran}

Berdasarkan hasil penelitian, peneliti dapat memberikan saran yaitu bagi investor yang akan menginvestasikan dalam bentuk saham harus lebih jeli dalam menganalisis dan melihat kinerja keuangan perusahaan sehingga perusahaan dapat memprediksi return. salah satunya bisa dilakukan dengan mengunakan rasio-rasio yang tepat untuk menilai apa yang menjadi landasan atau rujukan dalam berinvestasi. Contohnya rasio return on investment dan debt to equity ratio yang sudah terbukti memperngaruhi return saham. Selain itu, Bagi peneliti selanjutnya, disarankan untuk menambah variabel independen lainnya yang dapat mempengaruhi return saham. Contohnya volatilitas harga saham, Volume perdagangan dll.

\section{REFERENSI}

Aggrahini. 2014. Pengarub ROI, ROE, EPS Dan EVA Terbadap Return Saham Perusabaan Menufaktur Yang Terdaftar Di Bursa Efek Indonesia Periode 2009-2011. Jurnal Aplikasi Bisnis, Vol.3. No.1.

Akromon. 2009. Pengarub Rasio Kenangan (ROA Dan ROE) Dan EV A Terbadap Harga Sabam Pada Perusahaan Yang Terdaftar Di JII. Skripsi, Yogyakarata: Fakultas Syariah UIN Sunan Kalijaga.

Arsyad,Lincolin.2000. Ekonomi Manajerial. Yogyakarta : BPFE Yogyakarta.

Beranda. Produk Dan Layanan Pasar Syariah. Diambil Kembali Dari Www.Idx.Co.Id. Diakses Pada Tanggal 27 September 2017

Kasmir. 2014. Analisis Laporan Kenangan. Jakarta: Rajawali.

Eduardus, T. 2010. Portofolio Dan Investasi. Yogyakarta: Edisi Pertama.

Eka Novi Wijayanti, "Analisis Pengarub Kinerja Kenangaan Terbadap Return Saham pada Perusabaan Manufaktur yang Terdaftar di Bursa Efek Indonesia Tahun 2007 - 2009", Skripsi Thesis, 2012.

Eko, S. A. 2009. Analisis Statistik Dengan SPSS 16.0 Cet.1. Jakarta: Prestasi Pustaka Publisher.

Freizkhaana. 2013. Pengaruh Penilaian Kinerja Menggunakan Return On Investment, Earning Per Share, Price Earning Ratio, Return On Equity Terbadap Return Sabam (Studi Perusahaan Perbankekan Yang Listing Di Bursa Efek Indoneisa.

Gozali, I. 2006. Aplikasi Analisis Multivariance Dengan Program SPSS Edisi 3. Semarang: Badan Penerbitan Universitas Di Ponegoro.

Gozali, I. 2007. Aplikeasi Analisis Multivariance Dengan Program SPSS Edisi 4. Semarang: Badan Penerbitan Universitas Di Ponegoro. 
Gozali, I. 2013. Aplikasi Analisis Multivariance Dengan Program SPSS Edisi 7. Semarang: Badan Penerbitan Universitas Di Ponegoro.

Hadi, S. 2000. Seri Program Statistik Versi 2000. Yogyakarta: Universitas Gaja Mada.

Hasan, I. 1999. Pokok-Pokok Materi Statistik. 2. Jakarta: Bumi Aksara.

Hasley, W. S. 2009. Analisis Laporan Kenangan. Jakarta: Salemba Empat.

Irham, F. 2011. Analisis Laporan Kenangan. Bandung: Alfabeta.

Najmudin. 2011. Manajemen Kenangan Dan Aktualisasi Syariah Modern. Yogyakarta: C.V Andi.

Pinangkara, G. 2012. Return On Investment (ROI) Dan Ekonomi Value Added (EVA) Terbadap Return Saham Studi Khasus Pada Perusabaan Semen, PT.XYZ Yang Telah Go Publik Dan Memperdagangkan Sahamnya Di BEI Tabun 2005-2009. Jurnal Ilmu ManajemenVol.1 No 6, 156.

Rachmi Wijaya. 2009. Pengarub EPS dan ROI terbadap return sabam dalam sector industry automotive and allied products yang go public di BEI. Fakultas Ekonomi Universitas Widyautama

Raisa Fitri.2017. Pengaruh Kebijakan Dividen, Leverage Perusahaan dan Profitabilitas terhadap Return Saham (studi Pada perusabaan Sub Sektor Makanan dan Minuman Yang Terdaftar di BEI). JIBEKA VOLUME 11 NOMOR 2 FEBRUARI 2017 : 32 -37)

Rosiana. 2010. Pengaruh Leverage, ROI Dan ROE Terhadap Return Saham Pada Perusahaan Food And Beverage Yang Terdaftar Di BEI Periode 2005-2008.Jurnal Aplikasi Manajemen Keuangan Vol.2, 12.

Soemanto, Wasty. "Pedoman teknik penulisan skripsi”. (Jakarta: Bumi aksara, 2009), hlm 15

Sriwidodo, V. A. 2012. Analisis Faktor-Faktor Yang Memperngarubi Return Saham Investor Pada Perusahaan Manufaktur Di Bursa Efek Indonesia. Jurnal Wira Ekonomi Mikroskil Vol.1 No.01, 56-57.

Suad, H. 2007. Dasar-Dasar Teori Portofolio Dan Analisis Sekuritas. Yogyakarta: BFFE-UGM.

Sugiono. 2007. Metode Penelitian Bisnis. Bandung: Alfabeta.

Sunardi. 2010. Pengarub Penilaian Kinerja Dengan ROI Dan EVA Terbadap Return Sabam Pada Perusahaan Yang Tergabung Di Indeks LQ 45 Dibursa Efek Indonesia (BEI).

Suratno, Y. E. 2015. Pengarub Return On Equity, Debt To Equity Ratio, Price Earning Ratio, Assets Growth, Inflasi, Terhadap Return Saham Perusahaan Property Dan Real Estate.Jurnal Riset Akuntasi Dan Perpajakan JRAP Vol.2 No.2, 5-6.

Teguh, M. 2013. Metodelogi Penelitian Ekonomi (Teori Dan Aplikasi).

Wasty, S. 2009. Pedoman Teknik Penulisan Skripsi. Jakarta: Bumi Aksara.

Wijayanti, E. N. 2012. Analisis Pengaruh Kinerja Kenangan Terbadap Return Saham Pada Perusabaan Manufaktur Yang Terdaftar Di Bursa Efek Indonesia Tabun 2007-2009. Skripsi Thesis.

Yulianti Eka Budi dan suratno Return on Equity, Debt to Equity Ratio, Price Earning Ratio, Assets Growth, Inflasi, dan Return Saham Perusabaan Property dan Real Estate. Jurnal Riset Akuntansi dan Perpajakan JRAP Vol.2 No.2, Desember 2015 ISSN 2339-1545-. Hlm 5-6 